This is an Accepted Manuscript of an article published by Taylor \& Francis in Social \& Cultural Geography on 3 Sep 2020, available online: https://doi.org/10.1080/14649365.2020.1815826

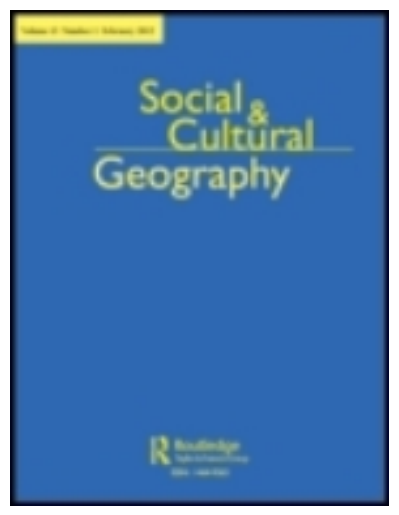

\title{
Three participatory geographers: reflections on positionality and working with participants in researching religions, spiritualities, and faith
}

\begin{tabular}{|c|l|}
\hline Journal: & Social and Cultural Geography \\
\hline Manuscript ID & RSCG-2019-0169.R2 \\
\hline Keywords: & $\begin{array}{l}\text { geographies of religion, participatory geographies, faith, spirituality, } \\
\text { positionality, researchers with faith }\end{array}$ \\
\hline & $\begin{array}{l}\text { This paper advances the geographies of religion, spirituality and faith's } \\
\text { limited attention to positionality by discussing the critical issues raised } \\
\text { when using participatory approaches. Reflecting on three cases of } \\
\text { participatory research, we foreground the dynamics of being a } \\
\text { researcher with faith when working with participants from faith } \\
\text { communities. Advocating participatory approaches as valuable } \\
\text { methodologies that should be used more extensively to explore beliefs, } \\
\text { faith practices, and social justice, we argue that greater attention needs } \\
\text { to be given to the positionality of researchers undertaking this sort of } \\
\text { research. Our cases raise three themes for discussion. First, the variety } \\
\text { of ways in which faith positionalities influence how research is } \\
\text { developed, conducted and concluded. Second, the intersections between } \\
\text { our faith and other positionalities and how they shape our roles and } \\
\text { relationships with research participants. Third, the fluid and multifaceted } \\
\text { nature of faith positionalities and how they are changed, emphasized, } \\
\text { and softened through the dynamics and entanglements of fieldwork. In } \\
\text { doing so, we reflect on the complexities of being a researcher with faith, } \\
\text { argue that faith positionality is a helpful dimension of their research } \\
\text { rather than a limitation, and that all cultural, social and historical } \\
\text { geographical researchers should reflect on their faith positionality. }\end{array}$ \\
\hline Abstractions
\end{tabular}

\section{SCHOLARONE" Manuscripts}




\title{
Three participatory geographers: reflections on positionality and working with participants in researching religions, spiritualities, and faith
}

\author{
Denning S. ${ }^{a *}$, Scriven R. ${ }^{b}$, Slatter, $\mathrm{R}^{\mathrm{c}}$. \\ *Corresponding author
}

\author{
${ }^{a}$ Coventry University; Centre for Trust, Peace and Social Relations, Cheetah Road, Coventry \\ University, Coventry. CV1 2TL \\ Email: stephanie.denning@,coventry.ac.uk; Twitter: @SJ_Denning; ORCiD: \\ https://orcid.org/0000-0002-1636-6539
}

bUniversity College, Cork; Department of Geography, University College Cork, Cork, Ireland Email: r.scriven@umail.ucc.ie; Twitter: @,RichardScrivGeo; ORCiD: https://orcid.org/0000$\underline{0002-4022-1655}$

'University of Hull; Department of Geography, Geology, and Environment, Cohen Building, University of Hull, Cottingham Road, Hull. HU6 7RX.

Email: R.Slatter@hull.ac.uk ; Twitter: @ruthslatter; ORCiD: https://orcid.org/0000-0001$\underline{5590-1410}$

\begin{abstract}
This paper advances the geographies of religion, spirituality and faith's limited attention to positionality by discussing the critical issues raised when using participatory approaches. Reflecting on three cases of participatory research, we foreground the dynamics of being a researcher with faith when working with participants from faith communities. Advocating
\end{abstract}


participatory approaches as valuable methodologies that should be used more extensively to explore beliefs, faith practices, and social justice, we argue that greater attention needs to be given to the positionality of researchers undertaking this sort of research. Our cases raise three themes for discussion. First, the variety of ways in which faith positionalities influence how research is developed, conducted and concluded. Second, the intersections between our faith and other positionalities and how they shape our roles and relationships with research participants. Third, the fluid and multifaceted nature of faith positionalities and how they are changed, emphasized, and softened through the dynamics and entanglements of fieldwork. In doing so, we reflect on the complexities of being a researcher with faith, argue that faith positionality is a helpful dimension of their research rather than a limitation, and that all cultural, social and historical geographical researchers should reflect on their faith positionality.

\section{Keywords}

Geographies of religion, participatory geographies, faith, spirituality, positionality, researchers with faith

\section{Introduction}

At the turn of the twenty-first century Lily Kong (1990 and 2001) called for the revision and revitalisation of the geographies of religion. Initially, scholars focused on explicitly 'religious' communities and the geographical nature of the theologically driven events they organized (Olson, 2008; Sanderson, 2008). In the subsequent decade, geographers of religion have considered an ever-expanding range of faith positions and spiritual practices (Bettis Gee \& Smith, 2015; Hopkins, Olson, Bailie Smith \& Laurie, 2015; Williams, 2016). While religious groups and their specific theological ideas are still discussed, there is an increasing 
Drawing together the experiences of three Christian geographers with varying faith positionalities undertaking participatory research with contemporary faith groups and activities, this paper specifically focusses on how our positionality as researchers with religious faith influenced our research processes. Using the experiences, alignments, and tensions of our individual fieldwork, we articulate the value in sharing faith with research participants, the role our faith played in influencing the inquiry process, and the resulting opportunities and challenges for working with groups and communities. Given the nature of this paper, we consider faith both as a concept and a personal attribute held by the researchers and participants. Our academic approach to the concept of faith is shaped by Brace et al.'s (2011, p. 3) discussion of faith as 'a belief-ful relationship with an object that cannot be accessed through doctrinal statement and ritual alone'. Therefore, we understand faith to be an emotional and spiritual connection with an entity beyond the self that is structured by theologies and practices, while being more than these manifestations. This position acknowledges faith as an objective category for researchers that is intimately linked with 
individual and collective identity and lifestyle choices. Alongside this definition of the concept of faith, is our appreciation of what faith means for us personally as 'a way of experiencing life, and a willingness to act' (Miles 2012, p. xvi) that is a component of our identities. The vignettes which follow expand on each of our faith experiences and actions and how they inform our positionality, and in doing so this paper will draw these parallel understandings of faith together. The dynamics and dialogue between our academic selves and our faith, informed by Slater's (2004) reflections, will form one of its key strands, enabling examinations of how geographers of faith can engage with their own and other religious communities.

The paper therefore contributes to recent developments within the geographies of religion, spirituality, and faith; participatory geographies; and the synergies in their meeting. We begin by framing our approach within participatory geographies, discussions of positionality, and the geographies of faith. Next, we each present a reflective vignette of our own faith positionality through recent participatory research. These three strands are then combined in a collective examination of the varying effects of researchers' faith positionalities; the intersections between our faith positionalities and other positionalities; and how our positionality changed in response to undertaking participatory research. We conclude the paper by outlining how our insights have the potential to influence further work in the geographies of religion, spirituality, faith, and beyond.

\section{Participatory geographies, positionality and faith}

While participatory approaches have gained prominence within geographical research (for example Kindon, Pain \& Kesby, 2009; Wynne-Jones, North \& Routledge, 2015), the potential insights that could be gained by utilising this methodology within the study of 
Our own research, as discussed in this paper, has identified three further benefits of participatory approaches within geographies of religion. First, how they allow scholars to understand how faith actions can have more meaning to faithful subjects than may at first be apparent (for example giving food is a physical activity but can also act out Biblical teaching (Denning, 2019)). Second, how they provide a means to engage with spirituality in people's daily lives, beyond sacred spaces and explicitly religious communities (Bartolini, MacKian, \& Pile 2019; Kong 2010; Sutherland 2016). Third, how they can facilitate a richer understanding of faith-based social action initiatives, for which participation and action are fundamental (see Bettis Gee \& Smith, 2015). As a result, this paper is an explicit call for more participatory research to be undertaken within geographical studies of religion.

However, if participatory approaches are more regularly utilized in the geographies of religion, greater attention also needs to be paid to the particular issues around positionality which arise when undertaking research into religion, faith, and spirituality. In non-religious 
contexts, human geographers have long discussed the issue of positionality and how researchers' identities influence relationships with participant communities. Over twenty years ago Gillian Rose (1997) articulated a feminist critique of positionality, highlighting both its fluidity and politics, while soon after Herod (1999) disrupted the neat dualism of insider-outsider by discussing the shifting contexts and complexities of research encounters. Having dispelled the artificiality of the detached observer, geographers have come to recognize and value their inherent involvement with participants and communities (Crang \& Cook, 2007). Encountering a vast range of practical, social, and ethical challenges, researchers have developed rigorous and self-reflexive work that acknowledges and evaluates their participation (Caretta \& Jokinen, 2017). In particular, participatory geographies emphasize positionality as a dimension of research contexts, which the researcher can enact upon, ideally for positive social change (Brydon-Miller, 2004). The role of the researcher and their positionality is key in participatory research, as is their willingness to learn rather than perceive themselves as experts extracting knowledge from participants (Wynne-Jones, et al., 2015). Crucial to this, is an appreciation of how positionalities can change over time and are not static throughout the research process. Therefore, at different times different elements of a researcher's positionality can be more significant and influential than others.

Just as participatory approaches have only recently begun to be utilized within the geographies of religion, faith, and spirituality, the positionality of those researching this area has received limited attention - whether they are utilising participatory methodologies or not. Adrian Bailey, Catherine Brace and David Harvey (2009) notably reflected on how their collaborative archival research into nineteenth-century Cornish Methodism was influenced by their differing faith and atheist positionalities. Our paper follows Bailey et al. with a discussion of faith and positionality from three geographers, but differs in that we are all 
Christian and each reflect on separate research projects. Terry Slater's (2004) autobiographical account of his experience of God remains one of the most prominent examinations of an individual's faith positionality, albeit in a personalized and contained setting. Significantly, Slater highlighted how 'few geographers speak as 'insiders' when writing about religious geography from whatever faith tradition' (p. 246). This caution may result from researchers with faith needing to justify their choice of religious subject and ability to be critical because it is often still the case that as Ethan Yorgason and Veronica della Dora (2009, p. 632) wrote, 'the identity of the religious geographer may often be stigmatized or considered taboo in most 'politically correct' and yet rigorously secular academic environments.' This is problematic, as shared faith is no more likely than another aspect of an individual's positionality to restrict a researcher's ability to be critical. Rather, as with any researcher's positionality, faith positionality holds both advantages and disadvantages which we draw out through our cases in this paper. In more recent additions to Slater's (2004) call for more insider approaches, Nina Laurie (2010) highlighted the need for researchers to be firm in their faith, while being open to the range of responses that may incur, and Claire Dwyer (2016) called for more critical approaches that respectfully recognize and engage with individual faith, including that of researchers. This paper's primary argument is that while more participatory approaches in the geographies of religion should be encouraged, there is also a clear need for greater consideration to be paid to researchers' positionality within this context.

\section{Faith, positionality and volunteering: Stephanie's reflections}

Over twenty months I established and ran a social franchise project (Lunch) in a church in a deprived inner city through the national Christian charity TLG. TLG MakeLunch kitchens respond to holiday hunger - children's food poverty in the school holidays - by running 
holiday clubs with free lunches. At Lunch I was both the project leader and a researcher. Lunch relied upon volunteers who were all aware of my role as a researcher, but participation in the research was voluntary with forty-two of the seventy-eight volunteers opting-in through interviews and/or writing diaries. I established Lunch with the intention of it continuing beyond the lifespan of the research and it was important to the ethics of the participatory research that Lunch did not run exclusively for research purposes, and aimed to make a sustainable response to holiday hunger in the community. Lunch had a Christian ethos, ran in a church hall, and the majority of volunteers were Christian, but there was no religious content at Lunch for the children.

Being Christian was an important aspect of my positionality in participatory research at a church. In this section, I explore how my Christian faith affected how Lunch unfolded and how I interpreted Lunch volunteers' narratives. My faith positionality was framed through being Anglican, a regular worshipper, and of a relatively liberal tradition. This 'type' of faith was similar to the majority of volunteers at Lunch. Like myself, the majority of volunteers were therefore comfortable with the lack of religious content for children at Lunch. That said, the church in which Lunch took place was more evangelical Anglican in its worship style which was different to my own background. It is therefore necessary to recognize that 'being Christian' is not a single positionality or universal category.

First, my faith affected how I as the project leader ran Lunch. Through my faith I emphasized social action for its own sake without evangelism which meant that we made Lunch open to all local children in the area, and put emphasis on food and play (see Cloke, Beaumont \& Williams, 2012 for a discussion of faith, social action and evangelism). Had I had a different understanding of the implications of faith for social action then how I established Lunch 
could have been different, for example with Biblical teaching. How I ran Lunch was also affected by my positionality in terms of commitment to the project continuing. I differed to Lunch volunteers in that my PhD research also depended on Lunch. However, relatively early on in running Lunch I felt that I had sufficient 'material' for the research, and so whatever happened next would change the narratives of the research analysis but not determine its success. To this extent my commitment to Lunch was more in terms of my faith and wanting the project to continue to respond to holiday hunger.

Despite the overall faith commonality between myself and volunteers, the church where Lunch ran was not a church that I worshipped at so I felt that I aroused suspicion from some church members in being both someone from outside the community and a researcher, and so it took time to develop genuine relationships. Volunteering regularly at the church youth group for six months before Lunch was launched was significant in gaining some trust. However, in July 2015 when Lunch first started, there was still wavering trust between myself and some key church members. This only truly became more positive after running Lunch again in October 2015, by which time relationships had developed and I had explicitly shown genuine intentions. However, my sharing of Christian faith with the group was significant in establishing a point of similarity between myself and the church community when in many respects I was an outsider, coming from a position of relative privilege. This is illustrated in my diary extract (09/03/2015) below from volunteering at the church youth group before establishing Lunch:

A lady I had not met before opened the door to me and I recognized her from the church website as [part of the church leadership]... She asked how I came to be there; "was I from church or secular?" 
In this example it was important to the lady I had just met whether I was from a church or not. Had faith not been an element of my positionality, it is questionable whether I would have been able to generate the church leadership's support for Lunch, whether the project would have had the same degree of success, and if the church would have continued running Lunch after I handed it over.

Secondly, my Christian faith affected how I understood and interpreted Lunch volunteers' narratives in the research. Being Christian allowed me to experience from 'within' the role that faith can play in volunteering. In particular, my faith helped me to recognize and understand people's narratives when they referred to faith as resulting in meaning that was more than what was represented (Denning, 2019), whereas this could have been missed had I not been familiar with faith language and faith connotations. One example is volunteer Violet's writing in her summer 2015 diary:

Just doing things doesn't change anything, there has to be some listening too and enabling people to change themselves. It wasn't us who got [child] to try jacket potatoes, it was his friends, a bit like the man being lowered into the house for Jesus to heal. (Violet, volunteer diary, 07/08/2015)

My faith gives an immediate understanding that Violet is referring here to a Biblical miracle of the paralysed man and that this is significant for understanding her first sentence. Would Violet have written in this way if I had been an atheist? This is not a question I have asked her, but from attending church together and coming from the same faith tradition, she would have known that I would 'get' this reference without her making it explicitly a Biblical citation. This is just one example of how my faith shaped how I was able to understand and interpret volunteers' narratives, showing how through our shared faith I was more readily able to understand moments that had meaning beyond what was represented. How faith 
shaped interpretation stretched further than this because it also made a difference that volunteers and I had shared experiences at Lunch and had been predominantly motivated to volunteer by our faith (Denning, forthcoming). This facilitated how I was able to interpret and write about my own and others' experiences in this research: being with people in an experience, and with a similar motivation gives a different starting point for analysis because the researcher starts with greater shared commonality with the participants and greater understanding of the nuances of that experience, than had they not also been there.

However, this is not to say that research in faith communities could not have been undertaken by someone without a faith positionality, nor that a shared faith positionality is superior or a universal category. As well as it being important to show my commitment to the church and to Lunch and to establish trust and positive relationships, in running a project responding to holiday hunger it was also necessary that I addressed a further element of my positionality: my relative economic privilege. Action researcher Mary Brydon-Miller (2004, p. 3) refers to the 'terrifying truth' of whether to act or not: fear of one's own privilege can reduce a person to inaction. Whilst I recognized my privilege and through this a degree of power, inaction would have been a poorer option than acting and acknowledging that power and positionality exist because ultimately, without my action in establishing Lunch, it would not have occurred in this area and church at this time. For example, I used academic grant writing skills to obtain three years of funding for Lunch. In this context, it was important to endeavour to lead the project sensitively and to recognize that my positionality changed over time as trust was gained, and relationships were developed. This was influenced by my Christian faith, but these reflections show that a shared faith positionality is not a panacea for participatory research. 


\section{Faith, positionality and pilgrimage: Richard's reflections}

On Lough Derg, a pilgrimage centre in the north-west of Ireland, I was a pilgrim. I was also a researcher focused on documenting and understanding the experience. My participation enabled engagement with fellow pilgrims to co-consider the character and impact of these spiritual journeys. As well as providing deep insight into the pilgrimage, it (unexpectedly) promoted examination of my faith.

Lough Derg blends an isolated lake-island with a set of centuries-old practices including fasting, keeping a twenty-four hour vigil, being barefoot, and performing a series of prayer stations. It is a retreat crafted from the remote landscape and a medieval aesthetic. While it is a Roman Catholic centre, it is open to those entering 'into a new stage in their lives and in their relationship with God' or for others seeking 'answers to life's questions and have come to pray for guidance, patience, courage and peace of mind' (Lough Derg, 2019). It is a what Turner \& Turner (1978) referred to as a 'liminal' location, as transitional space separate from the everyday enabling participants to engage in reflective and transformative journeys. My task was to enter this sanctuary with a hybrid identity as pilgrim-researcher.

My involvement was facilitated by the inclusive character of pilgrimages, which has been a central element to their revival. Individuals and groups can participate for overlapping personal, spiritual, and recreational motivations (Lopez, González, Fernández, 2017). I adopted an auto-ethnography to examine a range of experiences, including my own (Scriven, 2019). This approach is found in pilgrimage studies with Michalowski and Dubisch (2001) articulating an 'observant participation' to account for their intimate involvement as researchers and pilgrims, which has been adopted by others to situate their participation (Maddrell \& Della Dora, 2013; Maddrell and \& Scriven, 2016). Building on these 
trajectories, I harnessed opportunities to share experiences to co-produce knowledge, which presented different issues of positionality.

Given the research topic, the examination of my religious beliefs was relevant. At the time, I identified as a liberal Roman Catholic. In this setting my religious affiliation combined with other features of my identity as a White, Heterosexual, Irish, Settled, Catholic (WHISC) (Tracy, 2000) granting me considerable privilege. Having grown up Catholic in a Catholic majority country I was religiously and culturally embedded in the pilgrimage. I was an insider; other pilgrims recognized me as being of their milieu. Moreover, it was often assumed my research was religiously motivated, which assisted in gaining access. My privilege demanded on-going examination to ensure critical, rigorous research. An essential component of auto-ethnography is an on-going self-reflection/critique of my role and its relationship to the participants and the work (Sultana, 2007). I understood the practices as normative ways of expressing emotions and personal intentions; but, I am also a geographer who steps back to study these processes. Within the fieldwork and my subsequent interpretations, my faith emerged and re-emerged as a strand to critically examine.

The embodied nature of the pilgrimage and our shared journey allowed me to observe and discuss the beliefs with others in an intimate manner. This context enabled the abstraction of faith to be performed and felt in the mutual island experiences of ritual and fellowship. Particular insights were forged through these connections which need to be appreciated as emerging from the specifics of the context and people involved (see Alvesson 2003). Sitting together barefoot, our shared location enabled conversations through which understanding of the pilgrimage was co-produced. In these encounters, I had spiritual empathies with research participants and I had profoundly respectful responses, while at other times there was 
dissonance. My faith formed a thread within the process, generating affinities, affects, and frictions. This is a common pilgrim experience, you are brought in contact with a variety of different people which present opportunities for conversation, disagreement, and personal reflection (Frey, 1998). Simultaneously, encountering people you identify with, and others you do not, is a feature of social research (Moser, 2008).

Conversations with more liberal, usually younger, and even 'agnostic' Catholics were comfortable terrain. I recognized their dispositions as having a belief in something beyond themselves, which was manifest in irregular mass attendance. My faith position was buttressed as I felt solidarities. We were culturally Catholic together: it presented a ritualized existential framework while we separated ourselves from the Church's horrendous scandals and its socially conservative teachings. Other people resisted being referred to as religious, but understood themselves as everyday Catholics who worshiped weekly and tried to live good lives.

To different degrees, I also encountered pilgrims of considerable faith that was manifest in assorted forms. There were traditionalists who expressed support of Catholic doctrine on social matters, particularly concerning sexual 'morals' and gender identities. In these instances, there was a bifurcation of my pilgrim-researcher role, as I personally had (unspoken) issues with their perspectives, while they were also providing insight into their motivations. Aware of my roles as a researcher and a guest in the sanctuary, I let these comments pass without confronting them. Elsewhere, I met several pilgrims who conveyed a deep faith in talking about their motivations in praying for sick loved ones. The very personal motivation of Mary, one of the research participants, still sticks with me: 
What brought me anyway was I had a grandchild that I wanted to say prayers for special prayers. Eh, he had after been diagnosed with autism. So that's really why I came. To know would I get help and everything for him.

She firmly believed in pilgrimage as a means of seeking divine assistance and offering thanksgiving. In these moments, I viscerally and humbly witnessed the comfort and strength that religion offers people enduring hardships. Our shared conversation generated new understandings of pilgrimage, as a process that allowed people to explore and express their faith.

Meeting faiths that were similar and different to mine resulted in entanglements while underlining the value of my positionality in reaching new understanding. In my research diary, I recorded some of these impressions:

In talking, faith is many things (even for one person). It is religious, prayers and prescribed rituals; it is spiritual, an expression of forces beyond us and connections between us; it is belief in something, even when you are unsure what it is; it is a belief in the power of this place.

Lough Derg brought me into a renewed appreciation of faith as a complexity for most people that blends the transcendent and immanent through located practices. This liminal island enabled free discussion of this often unexplored topic, while also locating it in the mutual experience of the pilgrimage. It was by sharing this journey, by performing sets of prayer, and walking barefoot together with people that I reached these personally resonant insights.

While I went into my fieldwork conscious of my positionality, I was not prepared for faith to emerge as one of the more significant considerations. My research motivation has always been geographical interest. The spatial dimensions of religiosity/spirituality offered a distinct 
avenue to understand human experience and meaning-making. However, Lough Derg generated a shifting faith positionality as the beliefs of others and my attempts to understand these stances affected me. I found myself re-considering my faith as I tried to locate it in reference to others. Could it even compare to a sixty-something year old woman praying with all her being for a grandchild? Was 'cultural Catholicism' a cop out, neither willing to fully commit or completely leave? While these are questions that can occupy any interrogation of faith, they were framed within the pilgrimage/research. Ultimately, I became more assured of my identity as a progressive Christian - including a transition to the Church of Ireland - as my encounters with others presented a structure to understand what faith is and what it can be.

Pilgrimages are valued as combining physical practices and spiritual/personal reflections in potential-laden journeys. To travel with people and encounter their faith is a privilege of my work, and a component that affected me more than I had expected. My dual complementary role as pilgrim and researcher served to inform both dimensions strengthening my autoethnography and shaping my own faith. At Lough Derg, in the midst of prayers, fasting, and spiritual atmospheres, my fellows helped me to become a pilgrim.

\section{Faith, positionality and archival research: Ruth's reflections}

I engaged with a Methodist community in north London who were celebrating their bicentenary and reconstructing their church building. Starting as a public-heritage event, the project morphed into participatory research as it began to explore the impact of changing the church space on the contemporary congregation's everyday experiences of faith. Although historical geographers have demonstrated the possibility of using participatory methods (DeSilvey, 2007; DeLyser, 2014; Patchett, 2016), they have always 'participated' with longgone communities. This project was different because I used historical geography as a tool 
for participation with a contemporary community. Undertaken during the final year of my (entirely historical) $\mathrm{PhD}$, I approached this project as an opportunity to share my knowledge and archival skills for the benefit of a non-academic audience. While many academics are motivated to do the same for secular - often political - reasons, I was principally prompted by a personal form of Christian socialism. This not only inspires me to find the voices of ordinary people in historical archives, but also share these with contemporary congregations in order to emphasize the value of individuals and their personal experiences of church and faith today.

Between 2015 and 2016 the north-London Methodist community I worked with demolished and redeveloped their post-1945 building. While this (re)construction took place, the church's minister learned that the planned reopening was scheduled for exactly two-hundred years after the first Methodist church was opened on the same site. Assembling a team interested in Methodist history, local history, and community identity, the minister initially envisaged an exhibition to position the new building in its historical context. However, conversations with the minister and regular congregation members indicated that such a project would have been an unsatisfactory response to the church's requirements. As the church community prepared for its new building, they needed a context to discuss and reflect on the consequences of losing their old one and getting something new. Although the practicalities of this process had been discussed, the more personal and emotional effects of this change had been given less attention. Therefore, it seemed insufficient to educate the congregation about their church's history. Instead I drew on the archival approaches I had developed during my PhD to enliven the mundane stories of ordinary Methodist congregants in the nineteenth and twentieth centuries (Slatter, 2019), to inform a participatory project that used archives to give current congregation members an opportunity to reflect on their memories of, and 
experiences within their old church buildings, and express concerns about the design of the new church building and how it might impact their religious practices.

The exhibition format was maintained, but the process of developing it and the content it included were reconsidered. First, I undertook archival research into the church's history, but rather than reconstructing its architectural story I reflected on ways in which different congregation members had used and felt about their buildings over time. Before the exhibition I shared these insights with congregation members and gave them a chance to respond and add their own stories. In the exhibition, archival insights were displayed alongside art work by congregation members in response to their old buildings, portraits of congregants in the new building accompanied by oral history interviews, and interactive exhibits where visitors were invited to make their own visual responses to the new building.

In order to facilitate the co-production of material for the project's exhibition, I attempted to build relationships with members of the church's congregation by attending church services and activities. I hoped that by engaging in the community's religious practices I would be able to find commonalities that would demonstrate my interest in, and respect for congregants' experiences of the church space. However, I quickly realized that both my personal and professional positionalities made such relationships and conversations difficult. Although a Christian, with experience of being part of a nonconformist (Baptist) congregation and similar theological perspectives to this church and its congregants, these spiritual similarities were not consistently helpful and were at times detrimental. Initially, my personal faith and churchmanship were important: they focused my attention on the everyday aspects of religious practice within my broader research and motivated me to redesign this project so that it placed greater importance on congregants' personal experiences of faith. My 
faith and experiences of church also allowed me to build trusting relationships with the church's leadership. As a result, they not only trusted me with access to their properties and archives, but also allowed me to develop the project beyond their initial conceptions because I had demonstrated respect for, and agreement with, their theological aims.

However, my personal faith did little to help me build relationships with members of the congregation. Congregants were suspicious when I attended services, asking where I attended church, bemused that I would choose to worship with them rather than at my own church, and suspicious that this decision implied lack of commitment to my personal faith. Furthermore, similarities between the theology and churchmanship of the congregation and myself were largely undermined by the vast distinctions between other aspects of our identities. While I am a young white-British woman, most of the church's congregation members were retired and of West Indian origin. As a result, many congregation members were more comfortable talking to other members of the project team, who did not share their faith but were closer in age and life experience. Therefore, elements of my positionality beyond my religious faith were more important in influencing the effective co-production of knowledge with this community.

Indeed, further consideration of this project has suggested that it was my professional status, rather than my personal positionality, that most significantly impacted my attempts to coproduce knowledge with the church's community. Initially, my professional identity as a $\mathrm{PhD}$ student, my archival experience, and contextual knowledge of nineteenth- and early twentieth-century metropolitan Methodism, lead the church to approach me to participate in this project. The church leadership were aware that they had important archival documents, but not the knowledge or skill to analyse them. However, as the project developed my 
archival skills established me as the 'expert', a mediator between the congregation and what they considered to be distant and incomprehensible archival sources. Therefore, I was perceived as the sum of my academic skills, rather than an individual and using my archival skills to undertake research to share with the community complicated the equitable conversations I sought. The congregation often assumed that I knew best and that the information we could co-create would not be as valuable as the information in the archives. This was uncomfortable and unhelpful, creating a barrier between me and the church's congregation and making it difficult to gain insights into their memories and experiences of the church's old buildings.

Nevertheless, my attempts to undertake participatory research with the aid of archival research did provide some insights into the importance of faith spaces and materialities in individuals' everyday experiences of church. One former congregation member reflected on how some of their fondest memories of being part of this Methodist community revolved around fundraising for the demolition of the Victorian chapel and construction of the post1945 structure. While another noted how much they would miss the radiator in the vestry of the (now) demolished post-1945 church building, as it was where they had first prayed to God. Further work is required to more effectively integrate archival approaches within participatory methodologies and mitigate the impact that utilising archival skills has on the relationship between scholars and the communities they work with. For instance, rather than using my experience to interpret the archives, I could have trained members of the community. However, such a process requires extensive buy-in from the community, is time consuming, and therefore expensive. Therefore, it was not only infeasible within the limited time and budget that was available for this project, but probably for many others I may be involved in the future. 
More fundamentally, undertaking this project changed and raised questions about my positionality in ways I had not anticipated. Most particularly, my experience of how the differences between age, ethnic and educational identifiers had a greater impact on my relationships with members of this community than our shared faith perspectives, made me reflect on how personal identifying features are fundamental to peoples' experiences within faith spaces, but are rarely clear within the archive. Researching both the church's past and present also made me sincerely attached to this community. As a result, the way in which I have reflected on and written about this project has been imbued with a sense of care that goes beyond high ethical standards and I have to acknowledge that my positionality is not simply informed by my faith, personality, or professional identity, but also my attachment to this community and its members.

\section{Discussion}

There are three themes that draw our reflections together: first, how the researcher's faith positionality can have varying importance at different phases of research; secondly, the relationship between faith positionalities and other aspects of an individual's positionality; and thirdly, the relative and shifting nature of faith positionalities during the course of the research.

\section{The varying effects of researchers' faith positionalities}

Considering each phase of the research - choosing, beginning, interpreting data, closing the research - this section will explore the varying relevance of our faith positionalities during the process. An important frame to this discussion is that our faith positionalities were not static 
and, as explored in the third section of the discussion, our positionalities were changed by the research process.

Our different faith positions variously influenced how we chose to undertake the research projects. For example, Stephanie's Christian faith both motivated her to establish Lunch as part of her PhD research, and affected how she established Lunch as a faith-based project without religious teaching. Our faith positionalities proved both opportunistic and problematic as we began our research. Richard found that people assumed he held a faith motivation for his research which helped him to gain access. Initially Stephanie also found that her faith was advantageous in establishing relationships with gatekeepers and participants at Lunch because it mattered to them if she held a Christian faith. However, whilst Stephanie's faith was important in establishing relationships, this did not initially prove enough to override people's suspicions of her being in her twenties, a researcher, and from outside the local area; other aspects of Stephanie's positionality interacted with her faith in how others perceived her. For successful relationships to be established, Stephanie needed to show over time that she was committed to the church and that she could be trusted. Ruth also found that her faith positionality could be double-edged in how she established the research. Whilst she was primarily approached to undertake the research as a result of her archival skills, it was attractive to the church leader that they shared a theological positioning. However, Ruth then found that her shared faith was problematic in establishing relationships with members of the church community because they doubted the authenticity of her faith when she joined them for worship on Sundays; they questioned why she was not worshipping at her regular church. Overall, whilst our shared faith could be an opportunity and point of commonality as we established our research, it could also create suspicion, and other aspects of our positionalities could not be ignored. 
Next, our faith positionalities had varying effects on how we interpreted experiences and data in our research. Ruth has reflected that her faith encouraged her to place more emphasis upon individuals' personal experiences of faith and, as expanded upon in section three of this discussion, Richard felt challenged and humbled by others' faith views to such an extent that he moved from Catholicism to Anglicanism. For each of us, sharing a broad Christian faith positionality with our research participants gave us a particular understanding of their experiences. This is not to say sharing faith results in more effective research. Rather, it provided each of us with a particular set of insights because sharing this overall faith positionality gave a closer starting point and shared context for understanding faith participants' experiences. This is a position that we argue should be encouraged in participatory research, rather than continuously defended.

Finally, our faith positionalities could influence how the research ended. This was particularly notable for Stephanie, who early on in the process of running Lunch had 'enough' material for her $\mathrm{PhD}$ thesis to be secured but persevered in running Lunch because she felt through her faith that she had made a commitment to respond to holiday hunger. In this respect, Stephanie's faith affected both the running of Lunch and the direction that her PhD thesis took: the research looked not only at how Christians are motivated to volunteer to respond to holiday hunger, but also how they persist in volunteering. For Ruth, although there was a clearly defined end to her project (the completion of the exhibition and the bicentenary events), her shared faith with this community (particularly its leadership) has meant that her relationship with them has evolved into a friendship and she continues to be invited to events and contribute to the church's research into its past. 


\title{
The intersections between our faith positionalities and other positionalities
}

Examining our positionalities highlighted the inherent intersectionalities involved. While faith is the analytical priority for this paper, it remains one strand in our multifaceted identities which influenced the research process.

\begin{abstract}
A hierarchy of characteristics emerged for Ruth as congregation members found it easier to associate with researchers based on age and ethnicity rather than faith. These dynamics were unpredictable, disrupting the religious context of the research as other identifiers resonated more with the participants. In contrast, due to the relative uniformity of the pilgrim group, Richard's identification as a 'White, Heterosexual, Irish, Settled, Catholic' meant that he easily mixed with his fellows. On multiple levels he was an insider; however, he also found himself more aligned with some participants than others. Finally, as already mentioned, while Stephanie's faith helped to build trust with members of the church that hosted Lunch, her age, relative privilege, and status as geographical 'outsider' also complicated her relationship with this community. Each of our reflections highlight how researchers are multifaceted humans who bring a series of realities that impact on our work and how this can have a range of effects at different times.
\end{abstract}

A foundational element of participatory research is the acknowledgment of our role as researchers. We found that our professional function tended to be the key characteristic by which we were defined. This is especially present in Ruth's case where she was invited to participate by the Church leadership due to her expertise and skills. Therefore, while she was motivated by a desire to co-create knowledge with a Christian community, her status as an expert dominated her interactions with the group. Stephanie's case was more complex, in that she was the project leader and researcher, who was driven by the desire to establish a 
sustainable Christian response to holiday hunger. Some of her choices as leader, such as the role of faith/evangelism in the scheme, reinforced her formal role and affected relationships with volunteers. In each project, while being geographers with faith, the research role remained a central feature of our interactions. While there are nuances involved, rigorous self-reflection in participatory research needs to highlight this continuing reality.

This examination of our experiences has underlined the fluid and iterative nature of our work. As Herod (1999) discussed, positionality translocates through identities with some being (de)emphasized at different times and places. At points in our research, we were each more believer than academic, more geographer than co-participant, and vice-versa. Each of us occupied a 'space of 'betweenness"' having 'various levels of similarity and difference with the research participants' (Hopkins, 2009, p.6). A greater focus on our social skills and emotional negotiations is highly relevant in these circumstances (Caretta \& Jokinen, 2017; Moser, 2008). Although our faith positions proved advantageous in some circumstances, our interpersonal capacities were foundational to negotiating conditions in the field.

\section{How our positionality changed in response to undertaking participatory research}

Finally, because participatory research fundamentally prioritizes the co-production of knowledge between researchers and participants, it is necessary to reflect on how undertaking such research changes or influences a researcher's faith and may affect data interpretation.

Stephanie reflected on how undertaking this research reaffirmed her belief that faith should result in action to support individuals' practical needs. For Richard, undertaking this piece of participatory research contributed to a change in his faith position, leading to a growing awareness of his progressive Christian values and resulting in a reassessment of his 
faith. These experiences highlight the differences between each of our faith positionalities, but also how these faith positionalities changed over time in response to the research we undertook. Therefore, geographers - with faith or not - need to be aware of how engaging in participatory geographies of religion necessitates openness to the beliefs, practices, and experiences of those they are engaging with and remain alert to their - potentially changing faith positionalities while undertaking research with religious communities. Consequently, undertaking and weaving autoethnographies within such research is important, as it could make researchers more aware of the impact of the communities they are studying on their emotions and opinions, and could therefore contribute to the deconstruction of the barriers between researchers and subjects.

\section{Conclusions}

This paper has extended the limited attention to positionality in the geographies of religion, faith and spirituality by examining how participatory approaches to this area raise particular questions about researchers' positionalities. Our reflections have progressed considerations of who we are as geographers in relation to our study topic, fellow participants, and faith. This process has led us to critically respond to encounters in the field, alongside our individual and collective identities as researchers with faith. Building on the momentum surrounding participatory geographies, we encourage greater deployments of these approaches in the geographies of religion, spirituality, and faith. However, we argue that in order for these methods to be used successfully, more careful considerations of the nature and impact of positionality needs to be undertaken within geographical studies of religion. In particular, this paper primarily calls for - and is a step towards - greater critical reflection on: how researchers interact with faith communities and generate participative scholarship; the temporalities of positionalities, alongside the social and emotional character of fieldwork; and 
the fluid nature of positionality in relation to participants' stances. As there was a call for religion to be acknowledged as part of identity (Dwyer, 2016), so we now call for faith to be thoroughly incorporated into reflections on positionality.

Through our three vignettes, we have argued that sharing faith and experiences of religious ideas and practices with participants can be beneficial components of the research process, rather than features to be curtailed and kept private. Our case studies demonstrate that this mutuality grants researchers particular relationships with faith communities alongside analytical opportunities to provide detailed and located accounts of spiritual experiences and practices and to generate more inclusive forms of knowledge. As a result, faith positionality should be understood as a dimension of this work rather than a limitation. However, it is also important to clarify that belief is not a necessity or superiority, it is a strand of researchers' identities that is relevant to their choice of study and its performance. Furthermore, the personal nature of faith and variations between individuals and groups means that shared faith does not necessarily result in researchers having the same beliefs or experiences as their participants. Despite being three White, Western Christians undertaking participatory research within Christian communities, the relative nature of belief and variations between and within Christian groups produced differences and tensions. Clearly there is a need for geographers to reflect on this further within other ethnic, cultural and religious contexts, including consideration of researchers with faith who are engaging with communities of other faiths. Each of our vignettes illustrates that although personal faith contributed to our ability to build relationships, 'shared faith' is not a quick-fix for complete parity with, or understanding of faith groups. Indeed, a mutual faith can be a complication that prevents open conversations and builds mistrust between researchers and participants. 
Finally this paper makes three key contributions on positionality that resonate not only for faith-based research, but also other participatory and socially-oriented studies in geography and the wider academy. Firstly, there is a need for social, cultural and historical geographers to actively reflect on their moral and/or faith positions in their research. This is needed in order that the role of faith in both researchers' and participants' daily lives is taken seriously alongside other aspects of positionality and not left to the remit of geographers specifically focussing on faith. This is particularly relevant for researchers pursuing work for ethical reasons, particularly in challenging hegemonic neoliberal policies and practices, including social justice and climate activism. For this to be achieved, clear and honest conversations about faith and positionality need to be incorporated in all areas of academic practice including research publications, impact outputs and undergraduate teaching.

Secondly, this paper's foregrounding of faith provides a clear example of how positionality is not static, but ebbs and flows, and is multifaceted with different strands shaping researchers' interactions and connections with participants. Appreciation of this complex fluidity should be applied to other settings. Relationships with people, places, and non-human presences evolve affecting our analysis and approaches, while at different times gender, ethnicity, age, class, faith, is more relevant. Critical engagements with research praxis and reflections on interactions with participant communities demand more robust considerations of not only positionality, but how it evolves and shifts.

This leads to the third point that researchers are never isolated from the research process. As researchers with faith, we each found that our positionality - and even our personal faith was affected by the communities we engaged with. More broadly, all human geographers are feeling, thinking individuals who interact with and are influenced by other thinking, feeling 
humans. Therefore, we are all necessarily involved with our research, especially when using participatory approaches, which hence demands us to have tools that account for and reflect on this involvement, and mechanisms to support researchers engaging in more challenging and emotionally draining work.

\section{Acknowledgements}

The authors would like to thank the Editor and three anonymous reviewers for their comments on earlier versions of the paper. Thanks must also go to the communities which the authors worked with throughout their research.

\section{Funding}

The authors' research projects referred to in the paper were funded by the Economic and Social Research Council award number GEOG.SC3315; the Irish Research Council; the Wolfson Foundation and UCL's Train and Engage Fund.

\section{References}

Alvesson, M. (2003). Beyond neopositivists, romantics, and localists: A reflexive approach to interviews in organizational research. Academy of management review, 28, 1, 13-33.

Askins, K. (2018). Feminist geographies and participatory action research: co-producing narratives with people and place. Gender, Place \& Culture, 25, 1277-1294.

Bailey, A., Brace, C., \& Harvey, D. (2009). Three geographers in an archive: positions, predilections and passing comment on transient lives. Transactions of the Institute of British Geographers, 34, 254-269. 
Bartolini, N., MacKian, S., \& Pile, S., (2019). Spirit knows: materiality, memory and the recovery of Spiritualist places and practices in Stoke-on-Trent. Social \& Cultural Geography 20, 8, 1114-1137.

Bettis Gee, M \& Smith, R. (2015). Chapter 189. Moral Imperatives: Faith-Based Approaches to Human Trafficking. In: Brunn, S. (ed.) The Changing World Religion Map. Sacred Places, Identities, Practices and Politics. London: Springer, 3623-3648.

Brace, C., Bailey, A., Carter, S., Harvey, D. \& Thomas, N. (2011). Chapter 1. Emerging geographies of belief. In: Brace, C., Bailey, A., Carter, S., Harvey, D. \& Thomas, N. (eds.) Emerging Geographies of Belief. Cambridge: Cambridge Scholars Printing.

Brydon-Miller, M. (2004). The Terrifying Truth: Interrogating Systems of Power and Privilege and Choosing to Act. In P. Maguire, M. Brydon-Miller, \& A. McIntyre (Eds.), Travelling Companions: Feminism, Teaching and Action Research (pp. 3-19). Westport CT: Praeger Publishers.

Caretta, M.A., \& Jokinen, J.C. (2017). Conflating Privilege and Vulnerability: A Reflexive Analysis of Emotions and Positionality in Postgraduate Fieldwork. The Professional Geographer, 69, 275-283.

Cloke, P., Beaumont, J. \& Williams, A. (2012). Radical faith praxis? Exploring the changing theological landscape of Christian faith motivation. In: Beaumont, J. \& Cloke, P. (eds.) Faith-based organisations and exclusion in European cities. Bristol: Polity Press. Crang, M., \& Cook, I., (2007). Doing Ethnographies. SAGE, London. Denning S. (2019). Persistence in volunteering: an affect theory approach to faith-based volunteering, Social and Cultural Geography, Online first, 1-22.

Denning S. (forthcoming). Religious faith, effort and enthusiasm: motivations to volunteer in response to holiday hunger, Cultural Geographies. 
DeLyser, D. (2014). Towards a participatory historical geography Archival interventions, volunteer service, and public outreach in research on early women pilots, Journal of Historical Geography, 46, 93-98.

DeSilvey, C. (2007). Salvage Memory: constellating material histories on a hardscrabble homestead, Cultural Geographies, 14, 401-424.

Dwyer, C. (2016). Why does religion matter for cultural geographers? Social \& Cultural Geography, 17, 758-762.

Dwyer, C., Beinart, K. \& Ahmed, N. (2018) My life is but a weaving: embroidering geographies of faith and place, Cultural Geographies, 26, 113-140.

Frey, N.L. (1998). Pilgrim stories: on and off to the Road to Santiago. Univ. of California Press, Berkeley.

Herod, A., (1999). Reflections on interviewing foreign elites: praxis, positionality, validity, and the cult of the insider. Geoforum, 30, 313-327.

Hopkins, P. (2009). Women, Men, Positionalities and Emotion: Doing Feminist Geographies of Religion. ACME 8, 1-17.

Hopkins, P., Olson, E., Baillie Smith, M., \& Laurie, N. (2015). Transitions to Religious Adulthood: Relational Geographies of Youth, Religion and International Volunteering. Transactions of the Institute of British Geographers, 40, 387-398.

Kindon, S., Pain, R. \& Kesby, M. (2009). (eds.) Participatory Action Research Approaches and Methods. Connecting people, participation and place. 3rd edition ed. London: Routledge Kong, L., (1990). Geography and religion: trends and prospects. Progress in Human Geography 14, 355-371.

Kong, L., (2001). Mapping “new” geographies of religion: politics and poetics in modernity. Progress in Human Geography 25, 211-233. 
Kong, L., (2010). Global shifts, theoretical shifts: Changing geographies of religion. Progress in Human Geography, 34, 755-776.

Laurie, N. (2010). Finding yourself in the archives and doing geographies of religion.

Geoforum, 41, 165-167.

Lopez, L., González, R.C.L., \& Fernández, B.M.C. (2017). Spiritual tourism on the way of Saint James the current situation. Tourism Management Perspectives, 24, 225-234.

Lough Derg, (2019). Story of Lough Derg. Lough Derg website. Available at:

https://www.loughderg.org/story-of-lough-derg/ [accessed Feb 20 2019].

Maddrell, A., \& della Dora, V., (2013). Crossing surfaces in search of the Holy: landscape and liminality in contemporary Christian pilgrimage. Environment and Planning A, 45, 1105 $-1126$.

Maddrell, A., Scriven, R. (2016). Celtic pilgrimage, past and present: from historical geography to contemporary embodied practices. Social \& Cultural Geography, 17:2, 300321.

Michalowski, R.J., \& Dubisch, J. (2001). Run for the Wall: remembering Vietnam on a motorcycle pilgrimage. Rutgers University Press, New Brunswick, N.J.

Miles, S. (2012). Take This Bread, London: Canterbury Press.

Moser, S. (2008). Personality: a new positionality? Area, 40, 383-392.

Olson, E. (2008). Common belief, contested meanings: development and faith-based organisational culture. Journal of Economic and Social Geography, 99, 393-405.

Patchett, M. (2016). The taxidermist's apprentice: stitching together the past and present of a craft practice, Cultural Geographies, 23, 401-419.

Rose, G. (1997). Situating knowledges: positionality, reflexivities and other tactics. Progress in Human Geography, 21, 3, 305-320. 
Sanderson, E. (2008). Eschatology and development: Embodying messianic spaces of hope. Space and Culture, 11, 93-108.

Scriven, R. (2019). Journeying with: qualitative methodological engagements with pilgrimage. Area, 51, 540-548.

Slater, T. (2004). Encountering God: personal reflections on 'geographer as pilgrim'. Area, $36,245-253$.

Slatter R. (2019). Materiality and the extended geographies of religion: the institutional design and everyday experiences of London's Wesleyan Methodist circuits, 1851-1932, Journal of Historical Geography, 64, 60-71.

Sultana, F. (2007). Reflexivity, positionality and participatory ethics: Negotiating fieldwork dilemmas in international research. ACME, 6, 374-385.

Sutherland, C. (2016). Theography: Subject, theology, and praxis in geographies of religion. Progress in Human Geography, 41, 321-337.

Tracy, M., (2000). Racism and Immigration in Ireland: A comparative analysis (MPhil). Trinity College, Dublin, Dublin.

Turner, V.W., Turner, E. (1978). Image and pilgrimage in Christian culture: Anthropological Perspectives. Columbia U.P, New York.

Williams, A. (2016). Spiritual Landscapes of Pentecostal Worship, Belief, and Embodiment in a Therapeutic Community: New Critical Perspectives. Emotion, Society and Space, 19, 4555.

Williams, A. (2017). Residential Ethnography, Mixed Loyalties, and Religious Power: Ethical Dilemmas in Faith-Based Addiction Treatment. Social \& Cultural Geography, 18, 1016-1038.

Wynne-Jones, S., North, P., \& Routledge, P. (2015). Practising participatory geographies: potentials, problems and politics. Area, 47, 218-221. 
Yorgason, E., della Dora, V. (2009). Geography, religion, and emerging paradigms:

problematizing the dialogue. Social and Cultural Geography, 10, 629-637. 